\title{
Front Matter: Volume 9712
}

, "Front Matter: Volume 9712," Proc. SPIE 9712, Multiphoton Microscopy in the Biomedical Sciences XVI, 971201 (6 May 2016); doi: 10.1117/12.2239754

SPIE. Event: SPIE BiOS, 2016, San Francisco, California, United States 


\title{
PROGRESS IN BIOMEDICAL OPTICS AND IMAGING

\section{Multiphoton Microscopy in the Biomedical Sciences XVI}

\author{
Ammasi Periasamy \\ Peter T. C. So \\ Karsten König \\ Editors
}

14-16 February 2016

San Francisco, California, United States

Sponsored by

SPIE

Cosponsored by

Becker \& Hickl GmbH (Germany)

Carl Zeiss (United States)

Chroma Technology Corp. (United States)

Coherent Inc. (United States)

Semrock Inc. (United States)

ISS, Inc. (United States)

JenLab GmbH (Germany)

Leica Microsystems (United States)

Spectra-Physics ${ }^{\circledR}$, a Newport Company (United States)

Published by

SPIE 
The papers in this volume were part of the technical conference cited on the cover and title page. Papers were selected and subject to review by the editors and conference program committee. Some conference presentations may not be available for publication. Additional papers and presentation recordings may be available online in the SPIE Digital Library at SPIEDigitallibrary.org.

The papers reflect the work and thoughts of the authors and are published herein as submitted. The publisher is not responsible for the validity of the information or for any outcomes resulting from reliance thereon.

Please use the following format to cite material from these proceedings:

Author(s), "Title of Paper," in Multiphoton Microscopy in the Biomedical Sciences XVI, edited by Ammasi Periasamy, Peter T. So, Karsten König, Proceedings of SPIE Vol. 9712 (SPIE, Bellingham, WA, 2016) Six-digit Article CID Number.

ISSN: 1605-7422

ISSN: 2410-9045 (electronic)

ISBN: 9781628419467

Published by

SPIE

P.O. Box 10, Bellingham, Washington 98227-0010 USA

Telephone +1 3606763290 (Pacific Time) · Fax +1 3606471445

SPIE.org

Copyright (C) 2016, Society of Photo-Optical Instrumentation Engineers.

Copying of material in this book for internal or personal use, or for the internal or personal use of specific clients, beyond the fair use provisions granted by the U.S. Copyright Law is authorized by SPIE subject to payment of copying fees. The Transactional Reporting Service base fee for this volume is $\$ 18.00$ per article (or portion thereof), which should be paid directly to the Copyright Clearance Center (CCC), 222 Rosewood Drive, Danvers, MA 01923. Payment may also be made electronically through CCC Online at copyright.com. Other copying for republication, resale, advertising or promotion, or any form of systematic or multiple reproduction of any material in this book is prohibited except with permission in writing from the publisher. The CCC fee code is $1605-7422 / 16 / \$ 18.00$.

Printed in the United States of America.

Publication of record for individual papers is online in the SPIE Digital Library.

\section{SPIE. DIGITAL}

SPIEDigitalLibrary.org

Paper Numbering: Proceedings of SPIE follow an e-First publication model. A unique citation identifier (CID) number is assigned to each article at the time of publication. Utilization of CIDs allows articles to be fully citable as soon as they are published online, and connects the same identifier to all online and print versions of the publication. SPIE uses a six-digit CID article numbering system structured as follows:

- The first four digits correspond to the SPIE volume number.

- The last two digits indicate publication order within the volume using a Base 36 numbering

system employing both numerals and letters. These two-number sets start with 00, 01, 02, 03, 04, 05, 06, 07, 08, 09, OA, OB ... 0Z, followed by 10-1Z, 20-2Z, etc. The CID Number appears on each page of the manuscript. 


\title{
Contents
}

\author{
vii Authors \\ ix Conference Committee \\ xiii Introduction \\ xv JenLab Young Investigator Award
}

JENLAB YOUNG INVESTIGATOR AWARD PAPERS PRESENTATION

971202 Four-wave mixing based light sources for real-world biomedical applications of coherent Raman microscopy (JenLab Young Investigator Award) [9712-61]

971203 In vivo imaging flow cytometry based on laser scanning two-photon microscopy at $\mathrm{kHz}$ cross-sectional frame rate [9712-59]

\section{KEYNOTE SESSION}

971204 Correlated FLIM and PLIM for cell metabolism (Keynote Paper) [9712-1]

BIOMEDICAL APPLICATIONS OF COHERENT RAMAN II

$97120 \mathrm{H}$ Hyperspectral stimulated Raman scattering and multiphoton imaging for digital pathology of colonic disease [9712-13]

\section{COHERENT RAMAN TECHNICAL DEVELOPMENT}

$97120 M \quad M-C A R S$ and EFISHG study of the influence of a static electric field on a non-polar molecule [9712-19]

$97120 \mathrm{~N}$ Synchronized and timing-stabilized pulse generation from a gain-switched laser diode for stimulated Raman scattering microscopy [9712-20]

FLIM/FRET/FCS I

9712 OP Binding of the immunomodulatory drug Bz-423 to mitochondrial $F_{0} F_{1}-A T P$ synthase in living cells by FRET acceptor photobleaching (Invited Paper) [9712-22] 
9712 OQ Investigation of prostate cancer cells using NADH and Tryptophan as biomarker: multiphoton FLIM-FRET microscopy [9712-23]

FLIM/FRET/FCS II

9712 OR Temporal and spatial binning of TCSPC data to improve signal-to-noise ratio and imaging speed (Invited Paper) [9712-24]

9712 OS Tunable PIE and synchronized gating detections by FastFLIM for quantitative microscopy measurements of fast dynamics of single molecules (Invited Paper) [9712-25]

9712 OT ns-time resolution for multispecies STED-FLIM and artifact free STED-FCS (Invited Paper) [9712-26]

\section{TECHNOLOGY DEVELOPMENT I}

$97120 \mathrm{~V}$ Metabolic microscopy of head and neck cancer organoids [9712-29]

9712 0X A phasor approach analysis of multiphoton FLIM measurements of three-dimensional cell culture models [9712-31]

9712 OY Using multiphoton fluorescence lifetime imaging to characterize liver damage and fluorescein disposition in liver in vivo [9712-86]

\section{TECHNOLOGY DEVELOPMENT II}

971211 Recent developments in widely tunable and high peak power ultrafast laser sources and their adoption in biological imaging [9712-34]

\section{SECOND/THIRD HARMONIC GENERATION I}

971217 Characterization of human arterial tissue affected by atherosclerosis using multimodal nonlinear optical microscopy [9712-39]

971218 Forward versus backward polarization-resolved SHG imaging of collagen structure in tissues [9712-40]

\section{SECOND/THIRD HARMONIC GENERATION II}

9712 1D Multiphoton imaging with a nanosecond supercontinuum source [9712-45]

TECHNOLOGY DEVELOPMENT III

$97121 \mathrm{~F} \quad$ Large field of view multiphoton microscopy of human skin (Invited Paper) [9712-47]

iv 
$97121 G$ Design of a portable wide field of view GPU-accelerated multiphoton imaging system for real-time imaging of breast surgical specimens (Invited Paper) [9712-48]

$97121 \mathrm{H} \quad$ Compact fixed wavelength femtosecond oscillators as an add-on for tunable Ti:sapphire lasers extend the range of applications towards multimodal imaging and optogenetics [9712-49]

\section{TECHNOLOGY DEVELOPMENT IV}

$97121 \mathrm{M} \quad$ Multi-photon microscope driven by novel green laser pump [9712-54]

$97121 \mathrm{P} \quad$ Quantitative structural markers of colorectal dysplasia in a cross sectional study of ex vivo murine tissue using label-free multiphoton microscopy [9712-57]

POSTER SESSION

$97121 \mathrm{R}$ Observation of tendon repair in animal model using second-harmonic-generation microscopy (Student Poster Session Competition Award) [9712-70]

$97121 \mathrm{~S} \quad$ Nonlinear optical Stokes ellipsometric (NOSE) microscopy for imaging the nonlinear susceptibility tensors of collagen (Student Poster Session Competition Award) [9712-77]

$97121 \mathrm{~T} \quad$ Multiphoton fluorescence lifetime imaging of metabolic status in mesenchymal stem cell during adipogenic differentiation [9712-28]

$97121 \mathrm{~V} \quad$ Comparison of in vivo and ex vivo imaging of the microvasculature with 2-photon fluorescence microscopy [9712-60]

$97121 \mathrm{~W}$ The nature of multiphoton fluorescence from red blood cells [9712-63]

971212 In vivo two-photon imaging measuring the blood-brain barrier permeability during early postnatal brain development in rodent [9712-66]

971220 High-resolution stimulated Raman scattering microscopy by focal-field modulation [9712-67]

$971221 \quad$ Mapping of intracellular concentrations of macromolecules by two-photon excited fluorescence lifetime imaging [9712-69]

971222 In situ quantitative evaluation of osteoblastic collagen synthesis under cyclic strain by using second-harmonic-generation microscope [9712-71]

9712 2C Time-gated FLIM microscope for corneal metabolic imaging [9712-82]

$97122 \mathrm{E} \quad$ FLIM data analysis of NADH and Tryptophan autofluorescence in prostate cancer cells [9712-84] 
Proc. of SPIE Vol. $9712971201-6$

Downloaded From: https://www.spiedigitallibrary.org/conference-proceedings-of-spie on 26 Apr 2023 Terms of Use: https://www.spiedigitallibrary.org/terms-of-use 


\section{Authors}

Numbers in the index correspond to the last two digits of the six-digit citation identifier (CID) article numbering system used in Proceedings of SPIE. The first four digits reflect the volume number. Base 36 numbering is employed for the last two digits and indicates the order of articles within the volume. Numbers start with 00, 01, 02, 03, 04, 05, 06, 07, 08, 09, 0A, 0B...0Z, followed by 10-1Z, 20-2Z, etc.

\author{
Ahsen, Osman, 1G \\ Andersen, Peter E., $1 \mathrm{M}$ \\ Balu, Mihaela, $1 \mathrm{~F}$ \\ Baraige, Fabienne, 1D \\ Barbieri, Beniamino, OS \\ Baria, Enrico, 17 \\ Batista, Ana, 2C \\ Beier, Hope T., OR \\ Blanquet, Véronique, 1D \\ Börsch, Michael, OP \\ Breymayer, J., 04 \\ Brooker, Jeff, $1 G$ \\ Brucker, S. Y., OX \\ Bystrova, A. S., $1 T$ \\ Cable, Alex, $1 G$ \\ Cahill, Lucas, $1 G$ \\ Capitaine, E., OM \\ Chandra, Dhyan, $0 Q$ \\ Cicchi, Riccardo, 17 \\ Clausen, Mathias P., OT \\ Connolly, James L., $1 G$ \\ Coskun, Ulas, OS \\ Couderc, Vincent, OM, ID \\ Crawford, Darrell, OY \\ Cui, Meng, 03 \\ Dantus, Marcos, IW \\ DeWalt, Emma L., is \\ Djurhuus, Martin, 1M \\ Domingues, José Paulo, 2C \\ Dow, Ximeng Y., is \\ Dowler, Rhys, OT \\ Dudenkova, V. V., IT \\ Eggeling, Christian, OT \\ Erdmann, Rainer, OT \\ Evans, Conor L., IW \\ Fang, Yi-Cheng, ON \\ Faulkner-Jones, Beverly E., IG \\ Ferreon, Allan Chris, OS \\ Fujimoto, James G., $1 G$ \\ Galiani, Silvia, OT \\ Giacomelli, Michael G., IG \\ Glick, Gary D., OP \\ Gottschall, Thomas, 02 \\ Gräber, Peter, OP \\ Greening, Gage J., 1 P \\ Gusachenko, Ivan, 18 \\ Hakulinen, T., $1 \mathrm{H}$ \\ Hase, Eiji, 1R, 22 \\ Hornegger, Joachim, 1G
}

Hou, Jue, IF

Huang, Zhiwei, OG, 20

Husvogt, Lennart, $1 G$

Jauregui, Cesar, 02

Jensen, Ole Bjarlin, 1M

Johnson, Kathryn M., OP

Kalinina, S., 04

Kaneyasu, J. F., OM

Kano, H., OM

Klein, J., 11, 1H

Koberling, Felix, OT

Koenig, Marcelle, OT

Koletar, Margaret, IV

Kong, Lingjie, 03

Kraemer, Benedikt, OT

Kuzmin, Andrey, 21

Lai, Keith K., IP

Lakner, P. H., OX

Latour, Gaël, 18

Lefort, Claire, OM, 1D

Leproux, Philippe, OM, 1D

Lévêque, Philippe, 1D

Liao, Shih-Chu Jeff, OS

Limpert, Jens, 02

Lin, Jian, OG, 20

Liu, Lixin, 21

Louot, C., OM

Marti, Dominik, 1M

Massi, Daniela, 17

Matsubara, Oki, 22

Meleshina, A. V., $1 T$

Meyer, Tobias, 02

Mikami, Hideharu, IF

Minamikawa, Takeo, 1R, 22

Möller, Y., OX

Monaghan, M. G., OX

Morgado, António Miguel, 2C

Muldoon, Timothy J., IP

Murphy, Michael, IW

Nesi, Gabriella, 17

O'Connor, Rodney P., ID

Olayioye, M. A., OX

O'Melia, Meghan J., OQ, 2E

Opipari, Anthony W., Jr., OP

Osseiran, Sam, IW

Ould-Moussa, N., OM

Ozeki, Yasuyuki, ON

Pagnoux, D., OM

Patting, Matthias, OT 
Pavone, Francesco S., 17

Peng, Xiao, 21

Periasamy, Ammasi, OQ, 2E

Petersen, Jan, OP

Pliss, Artem, 21

Popp, Jürgen, 02

Potma, Eric O., $1 \mathrm{~F}$

Prasad, Paras N., 21

Prieto, Sandra P., 1P

Qu, Junle, 21

Quadrado, Maria João, 2C

Rehman, Shagufta, OQ, 2E

Reisch, Paja, OT

Roberts, Michael S., OY

Rodríguez-Contreras, Adrián, 12

Rotellini, Matteo, 17

Rück, A., 04

Sato, Katsuya, 1R, 22

Saytashev, llyas, IW

Schanne-Klein, Marie-Claire, 18

Schenke-Layland, K., OX

Schmitt, Michael, 02

Schmitt, Paul D., is

Shah, Amy T., OV

Sheykin, Yury, $1 G$

Shi, Lingyan, $1 Z$

Shirmanova, M. V., IT

Silva, Susana F., 2C

Simpson, Garth J., is

Skala, Melissa C., OV

Sled, John G., IV

Spence, Dana M., IW

Starke, Ilka, OP

Stefanovic, Bojana, IV

Steinman, Joe, IV

Studier, Hauke, OY

Sullivan, Shane Z., $1 S$

Sun, Yuansheng, OS

Svindrych, Zdenek, $0 \mathrm{Q}, 2 \mathrm{E}$

Takahashi, Mitsuhiko, IR

Tang, Jianyong, 03

Tannert, Sebastian, OT

Thorling, Camilla A., OY

Teulon, Claire, 18

Tokunaga, Kyoya, ON

Tombelaine, Vincent, 1D

Tromberg, Bruce J., IF

Tünnermann, Andreas, 02

Vardeh, Hilde, $1 G$

Wallrabe, Horst, $\mathrm{OQ}, 2 \mathrm{E}$

Walsh, Alex J., OR

Wang, Zi, OG

Yasui, Takeshi, 1R, 22

Yokoyama, Hiroyuki, ON

Yoshitake, Tadayuki, $1 \mathrm{G}$

Zagaynova, E. V., IT

Zheng, Wei, OG, 20 


\title{
Conference Committee
}

\author{
Symposium Chairs
}

James G. Fujimoto, Massachusetts Institute of Technology

(United States)

R. Rox Anderson, Wellman Center for Photomedicine, Massachusetts General Hospital (United States) and Harvard School of Medicine (United States)

Program Track Chairs

Ammasi Periasamy, University of Virginia (United States)

Daniel L. Farkas, University of Southern California (United States) and Spectral Molecular Imaging, Inc. (United States)

Conference Chairs

Ammasi Periasamy, University of Virginia (United States)

Peter T. C. So, Massachusetts Institute of Technology (United States)

Karsten König, Universität des Saarlandes (Germany)

\section{Conference Program Committee}

Wolfgang Becker, Becker \& Hickl GmbH (Germany)

Alberto Diaspro, Istituto Italiano di Tecnologia (Italy)

Chen-Yuan Dong, National Taiwan University (Taiwan)

Kevin W. Eliceiri, University of Wisconsin-Madison (United States)

Scott Fraser, The University of Southern California (United States)

Paul M. W. French, Imperial College London (United Kingdom)

Hans C. Gerritsen, Universiteit Utrecht (Netherlands)

Enrico Gratton, University of California, Irvine (United States)

Min Gu, Swinburne University of Technology (Australia)

Stefan W. Hell, Max-Planck-Institut für Biophysikalische Chemie (Germany)

Paul J. Campagnola, University of Wisconsin-Madison (United States)

Satoshi Kawata, Osaka University (Japan)

Fu-Jen Kao, National Yang-Ming University (Taiwan)

Arnd K. Krueger, Spectra-Physics ${ }^{\circledR}$, a Newport Company

(United States)

Joseph R. Lakowicz, University of Maryland School of Medicine

(United States)

Steve M. McDonald, Coherent, Inc. (United States)

Angelika C. Rueck, Universität Ulm (Germany) 
Junle Qu, Shenzhen University (China)

Steven S. Vogel, National Institutes of Health (United States)

Paul W. Wiseman, McGill University (Canada)

$X$. Sunney Xie, Harvard University (United States)

Chris Xu, Cornell University (United States)

Bernhard Zimmermann, Carl Zeiss Jena GmbH (Germany)

Warren R. Zipfel, Cornell University (United States)

\section{Session Chairs}

1 Keynote Session

Karsten König, Universität des Saarlandes (Germany)

2 Biomedical Applications of Coherent Raman I

Eric Potma, University of California, Irvine (United States)

3 Biomedical Applications of Coherent Raman II

Ji-Xin Cheng, Purdue University (United States)

4 Coherent Raman Technical Development

Marcus T. Cicerone, National Institute of Standards and Technology (United States)

5 FLIM/FRET/FCS I

Yuansheng Sun, ISS, Inc. (United States)

6 JenLab Young Investigator Award Papers Presentation

Karsten König, Universität des Saarlandes (Germany)

7 FLIM/FRET/FCS ॥

Michael Börsch, Friedrich-Schiller-Universität Jena (Germany)

8 Technology Development I

Peter T. C. So, Massachusetts Institute of Technology (United States)

9 Technology Development II

Peter T. C. So, Massachusetts Institute of Technology (United States)

10 Second/Third Harmonic Generation I

Conor Evans, Harvard School of Medicine (United States)

11 Second/Third Harmonic Generation II

Paul J. Campagnola, University of Wisconsin-Madison (United States)

12 Technology Development III

Francesco S. Pavone, European Laboratory for Non-linear Spectroscopy (Italy) 
13 Technology Development IV

Karsten König, Universität des Saarlandes (Germany)

Poster Session

Holly Aaron, University of California, Berkeley (United States)

Kevin W. Eliceiri, University of Wisconsin-Madison (United States)

Alex J. Walsh, Air Force Research Laboratory (United States)

Proc. of SPIE Vol. $9712971201-11$

Downloaded From: https://www.spiedigitallibrary.org/conference-proceedings-of-spie on 26 Apr 2023 Terms of Use: https://www.spiedigitallibrary.org/terms-of-use 
Proc. of SPIE Vol. 9712 971201-12

Downloaded From: https://www.spiedigitallibrary.org/conference-proceedings-of-spie on 26 Apr 2023 Terms of Use: https://www.spiedigitallibrary.org/terms-of-use 


\section{Introduction}

Multiphoton microscopy has been established as the 3D imaging method of choice for studying biomedical specimens from single cells and whole animals to patients with submicron resolution. 25 years have passed since the realization of two-photon laser scanning microscopy. The ever-expanding scope of applications and the continuing instrumental innovations require a forum where new ideas can be exchanged and presented. Our conference at the SPIE BIOS 2016 meeting continues to address this need.

The 16th year of this conference began with three keynote lectures from leaders in the field: Angelika C. Rueck, Universität Ulm (Germany), "Correlated phosphorescence and fluorescence lifetime imaging for cell metabolism" [9712-1]; Peter T. C. So, Massachusetts Institute of Technology (United States), "Depth-resolved incoherent and coherent wide-field high-content imaging" [9712-2]; and Xiaoliang S. Xie, Harvard University (United States), "Biomedical applications of SRS microscopy" [9712-3].

For the 5th year in a row, the conference was extremely pleased to have the JenLab Young Investigator Award in addition to our regular poster awards. This award was donated by Karsten König, President and Founder of JenLab GmbH (Germany). The award selection committee included Arnd Krueger, Spectra Physics ${ }^{\circledR}$, a Newport Company (United States), Francesco S. Pavone, Università degli Studi di Firenze (Italy), Paul J. Campagnola, University of Wisconsin-Madison (United States), and the two conference chairs, Karsten König and Peter T. C. So. The selection process included the abstract, manuscript, and poster presentation. Two finalists were selected for oral presentation after their poster presentations.

The two finalists were

1. Lingjie Kong, Purdue University (United States), for "In vivo imaging flow cytometry based on laser scanning two-photon microscopy at kHz cross-sectional frame rate" [9712-59], and

2. Thomas Gottschall, Friedrich-Schiller-Universität Jena (Germany), for "Four-wave mixing based light sources for real-world biomedical applications of coherent Raman microscopy" [9712-61].

Thomas Gottschall, Friedrich-Schiller-Universität Jena (Germany) was selected as the winner of the JenLab Young Investigator Award 2016.

For the 16th year in a row, the conference organized poster awards for students and postdoctoral fellows. The poster awards were donated by our conference sponsors, including: Becker \& Hickl GmbH, Chroma Technology Corp., Coherent Inc., ISS, Inc., Spectra Physics ${ }^{\circledR}$, a Newport Company, Leica Microsystems, Semrock Inc., and Carl Zeiss. 
The 3 poster award winners were:

1. Hequn Wang, Massachusetts General Hospital (United States), for "Noninvasive visualization of pheomelanin using coherent Raman scattering microscopy" [9712-62],

2. Eiji Hase, The University of Tokushima (Japan), for "Observation of tendon repair in animal model using second-harmonic-generation microscopy" [9712-70], and

3. Ximeng You, Purdue University (United States), for "Nonlinear optical Stokes ellipsometric (NOSE) microscopy for imaging the nonlinear susceptibility tensors of collagen" [9712-77].

Some of the most valuable contributions in this volume are articles written by highly experienced practitioners of multiphoton microscopy. They have enumerated the most important considerations in designing multiphoton microscopes and imaging experiments. Further, updates on the state-of-the-art commercial multiphoton microscope systems were presented. This volume also includes proceedings describing some recent advances in major multi-photon microscope components and applications, including laser light sources, ultra-fast optics, filters, FRET, FLIM, FCS, Raman, CARS, SRS and CRS microscopy and spectroscopy, single molecule, endoscopy, energy metabolism measurements including NADH, FAD, tryptophan in cells and tissues, and various scientific and clinical applications.

On a personal note, the conference chairs are grateful for the participation of all authors and session chairs, and acknowledge the innovation-driven manufacturers and sponsors of this conference (Becker \& Hickl GmbH, Chroma Technology Corp., Coherent Inc., ISS, Inc., JenLab GmbH, Spectra-Physics ${ }^{\circledR}$, a Newport Company, Leica Microsystems, Semrock Inc., and Carl Zeiss) for their enthusiastic support in organizing this conference successfully for the last 16 years. We look forward to other exciting conferences in the future and welcome your continued participation and support. 


\title{
JenLab Young Investigator Award
}

\author{
presented to \\ Thomas Gottschall \\ Friedrich-Schiller-Universität Jena (Germany) \\ for
}

Four-wave mixing based light sources for real-world biomedical applications of coherent Raman microscopy [9712-61]

\section{Session Chair}

Peter T. C. So, Massachusetts Institute of Technology (United States)

Award Presenter

Karsten König, President of JenLab GmbH (Germany) 
Proc. of SPIE Vol. 9712 971201-16

Downloaded From: https://www.spiedigitallibrary.org/conference-proceedings-of-spie on 26 Apr 2023 Terms of Use: https://www.spiedigitallibrary.org/terms-of-use 